Jurnal Keperawatan Padjadjaran

ISSN 2338-5324 (print)

ISSN 2442-7276 (online)

Online di http://jkp.fkep.unpad.ac.id

DOI : $10.24198 / \mathrm{jkp}$

\title{
Tera Gymnastic Effective for Patient with Hypertension
}

\author{
Hesti Platini, Sandra Pebrianti, Indra Maulana \\ Faculty of Nursing, Universitas Padjadjaran, Bandung, Indonesia \\ Corresponding email: hesti13001@unpad.ac.id
}

Submitted: 24-08-2018 Accepted: 16-09-2019 Published: 05-12-2019

\begin{abstract}
Hypertension is a cardiovascular disease globally. Hypertension is remains silent killer, the clinical strategy to focusing on new and improved treatments is exercise. Tera gymnastics is a physical and mental exercise, combining the movement of body parts with breathing techniques and rhythms through the concentration of thought that is carried out regularly, harmoniously, correctly and continuously, Physical activity can reduce high blood pressure. Some study showed Regular physical activity is an effective intervention with respect to these factor, decreasing mortality rate for cardiovascular disease and all cause of disease in hypertensive patient. Gymnastic Tera exercise can help to control metabolic variable related to hypertension. The study was use quasy experimental design with one group pretest-posttest. The study was conducted in Puskesmas Pasundan Garut. Sampling in this study is subjects that is criteria patients has hipertension with 8 weeks treatment so will take methode of concecutive sampling with 15 respondents for intervention group and 15 for control group. The sample were age 30-55 years. The Intervention was gymnastic tera exercise. The Blood pressure function was evaluated before and after the training period. The data were analyzed by using t-test paired. The result showed a significant difference before and after tera gymnastic exercise in patient with hypertension I $(\mathrm{p}=000.0)$. Result of systolic blood presure when in mean SD pretest is 146.00 higher than post test is 136.00 in intervention group. The tera gymnastic exercise conditioning program achieved effect in this population. The reduction of blood pressure after exercise is of great clinical relevance. The increased risk of physical inactivity in controlling hypertension in our study suggest that general practitioners must be in the habit of prescribing practice of physical exercise. Physical activity has been shown to have beneficial effect on blood pressure. patients are followed up regularly to confirm that they are adhering to the management plan and the blood pressure targets.
\end{abstract}

Keywords: Exercise, gymnastic tera, hypertension. 
Hesti Platini: Tera Gymnastic Effective for Patient with Hypertension

\section{Introduction}

Hypertension is one of the most deadly chronic diseases in the world by contributing 9.4 million mortality every year (WHO, 2013) in Kharisna, Ropi, and Rahayu (2018). High blood pressure is the risk of risk cardiovascular disease (CVD) and all cause of mortality. Data from the World Health Organization (WHO) in 2015 showed that around 1.13 billion people in the world have hypertension, Meaning that 1 in 3 people in the world is diagnosed with hypertension. The number of people with hypertension continues to increase every year, it is estimated that in 2025 there will be 1.5 billion people affected by hypertension, and it is estimated that every year 9.4 million people die from hypertension and its complications. (Depkes.go.id). Hypertension is risk factor for more cardiovascular heart disease. High blood pressure condition increase risk of heart attack, hearth failure, and, sudden cardiac death (Arima, 2011). Patient often fail to recognize essensial high blood pressure as a disease until it is identified by a physician. If we successfully control blood pressure with a healthy lifestyle, we might avoid, delay or reduce the complication from hypertension. Reducing high blood pressure can decreased cardiovascular by achived by non-pharmacological. Lifestyle change should be the initial approach to hypertension management and include physical exercise (Gupta \& Ghupta, 2010). Exercise training has an important role in the prevention and treatment of high blood pressure.

Exercise is the key of management hypertension. However, the overall low of studies and lack of data about exercise. Some people who incapable, weak, and sickly person cause them to treat the helpless human, so that all activities are very limited. This condition is exacerbated by the lack of time, place, and opportunity for their doing activities to fill the rest of his life. Therapy of hypertension focuses on pharmacology. Those therapy are affecting on physiological mechanism. For holistic approach, hypertensive people need combined the conventional therapy with modalities therapy. One of modalities therapy for reduce high blood pressure are by exercise. Exercise is recommended as one of lifestyle intervention in the treatment of hypertension by many guidelines (PeriOkonny, Fu, Zhang, \& Vongpatanasin, 2015). Moderate intensity aerobic one of the management for hypertension. Aerobic has direct effect of blood pressure. But there insufficient evidence about the safety and efficacy of isometric resistance training to recommended it. But not all hypertension patients are allowed this exercise. Aerobic has been proven and prevent hypertension for help management hypertension stage 1 (Ghadieh \& Saab, 2015). Another exercise for hypertensive patient not only moderate intensity aerobic, but also tera gymnastic. Therefore, the people need to maintain the condition of his body by exercise, one of them is tera gymnastics. Tera gymnastics is light, gentle and easy for all ages.

Tera gymnastics is a physical and mental exercise, combining the movement of body parts with breathing techniques and rhythms through the concentration of thought that is carried out regularly, harmoniously, correctly and continuously (Eriyanti et.al., 2016). Continuous exercise training is the type of physical activity most frequently recommended to hypertensive subject. Regular physical activity is an effective intervention with respect to these factor, decreasing mortality rate for cardiovascular disease and all cause of disease in hypertensive patient (Guimaraes et al., 2010). In addition tera gymnastic help to control metabolic variable related to hypertension.

Training has an important role in the prevention and treatment of hypertension (Giolac et al, 2010). Exercise training is the type of physical activity most recommended to hypertensive subject. Training for hypertensive patient has many benefit, such as helping patient to their physical activities before the disease, optimizing body physical, and preventing complication. However, the rate about tera gymnastic participation both worldwide and Indonesia still low. There are not many patient actively participate. This study aims to determine the influence of tera gymnastics on blood pressure in hypertension patients and to demonstrate the effect of physical activity on controlling blood pressure So the benefit of this research is to know how big the benefits of tera gymnastics 
Hesti Platini: Tera Gymnastic Effective for Patient with Hypertension

against blood pressure hypertension patients. Tera gymnastics gives effect to the heart system and blood gain in improving its ability. More blood vessels (small blood vessels) are built in active tissue to regulate food and oxygen supply, and exercise consumes more in the system and inhibits fat reserves in blood vessels, thereby reducing the risk of thrombosis Hardjana (2000) in Eriyanti et al. (2016).

\section{Method}

The study was quasy experimental design with one group pretest-posttest. Sampling by means of concecutive sampling with 15 respondents for intervention group and 15 for control group. Inclusion criteria : Patients with stage 1 hypertension, kooperatif, willing to be respondent, there is no history of diabetes, had quit smoking less than 3 months. The sample were age $30-55$ years, because after the age of 30 years there is a $1 \%$ decrease in heart pulmonary fitness every one year of age which is an indicator of oxygen consumption by the heart and lungs, the pulmonary heart fitness will decrease by $35 \%$. The Intervention was tera gymnastic exercise.
The study was conducted in Puskesmas Pasundan Garut with the most incidents of hypertension. All patient attended an exercise training programmed three time a week for a period of 8 weeks. The Blood pressure function were evaluated before and after the training period. Blood pressure monitoring was performed at base line and follow up with .The data were analyzed by using t-test paired to compared two group, group intervention and control group. Participants were instructed to practice their gymnastic tera daily throughout the 8-week intervention phase. During screening sessions blood pressure was recorded posttest and pretest for total 2 measurements per session. The blood pressure recorder was calibrated using in sphygmomanometer.

\section{Results}

That population has met the inclusion criteria of 15 person $(\mathrm{X} 1=15, \mathrm{X} 0=15)$. Research subjects were selected with high blood preasure. Tera gymnastic exercise was associated with a significant reduction in mean systolic and diastolic blood pressure. Characteristic respondent in this research is

Table 1 Results of Homogeneity Test by Age Tera Gymnastic Group and Control Group

\begin{tabular}{|c|c|c|c|c|c|}
\hline \multirow[t]{3}{*}{ Variable } & \multicolumn{2}{|c|}{ Gymnastic Tera Group } & \multicolumn{2}{|c|}{ Control Group } & \multirow[t]{3}{*}{ P value } \\
\hline & & & \multirow[t]{2}{*}{$n=15$} & & \\
\hline & $\mathbf{F}$ & $\%$ & & $\%$ & \\
\hline $35-40$ & 4 & 23.7 & 5 & 33.3 & 0.525 \\
\hline $40-55$ & 11 & 76.3 & 10 & 66.7 & \\
\hline
\end{tabular}

Tabel 2 Average Differences of Pretest and Posttest Results Blood Pressure Hypertension Between Tera Gymnastic Group with Control Group

\begin{tabular}{llccc}
\hline \multicolumn{1}{c}{ Group } & N & $\begin{array}{c}\text { Prettest } \\
\text { Mean (SD) }\end{array}$ & $\begin{array}{c}\text { Posttest } \\
\text { Mean (SD) }\end{array}$ & P-Value \\
\hline Intervention Group & 1 & & & 0.001 \\
Systolic & 5 & $146.00(0.114)$ & $136.00(0.007)$ & \\
Diastolic & & $91.02(0.108)$ & $89.20(0.002)$ & \\
Control Group & 1 & & & \\
Systolic & 5 & $145.00(0.118)$ & $144.20(0.101)$ & \\
Diastolic & & $91.00(0.110)$ & $90.02(0.108)$ & \\
\hline
\end{tabular}


patients with hypertention with 1 st grade .

The two group had similar age, office blood pressure and current medication distribution. And the 30 subject completed the protocol. This is proven by the value of $p$ value that was bigger than $\alpha(0.05)$.

Based on the table above, it can be explained that the average difference of blood pressure between group of tera exercise is p-value $=$ $0.001(\alpha<0.05)$, this can be interpreted there is difference between group of control after given exercise. From the description of the research results obtained the average. The reduction in blood pressure have been shown to occur after only 4 weeks in individuals with elevated high blood pressure. The result showed a significant difference before and after tera gymnastic exercise in patient with hypertension $\mathrm{I}(\mathrm{p}=0.000)$. That tera gymnastic exercise decrease systolic and diastolic blood pressure.

\section{Discussion}

This study shows that gymnastics can produce effects on decreasing blood pressure. Effects of decreased blood pressure in hypertensive patients on normotensive people. Therefore, exercise contributes to the control of blood pressure in hypertensive patients and is likely to contribute to the prevention of hypertension in normotensive subjects. Aerobic is an effective method to lower blood pressure and improve other cardiovascular risk factor (Hansen et al, 2011). Tera exercise group is more effective than control group, its significant different before and after exercise. gymnastics tera can improve fitness in the elderly (Nursalam, 2009). Low exercise activity physical as gymnastics, also can cause hypertension due decreased cardiac output pumping to the heart becomes more reduced.

The frequency relationship of tera gymnastics against systolic blood pressure shows a strong relationship. High blood pressure is systolic pressure of more than $140 \mathrm{mmHg}$ and diastolic blood pressure more than $90 \mathrm{mmHg}$. Hypertension is a multifactorial disease which arises due to various interactions factor. Blood pressure will increase after aged 45 - 55 years, the walls of the arteries will be thickening by the presence accumulation of collagen substances in the muscle layer, so that blood vessels will gradually narrowed to rigid. Enhancement age will cause some changes physiologically, there is an increase peripheral resistance and sympathetic activity.

Blood pressure and heart rate both rise when exercise. It can lower blood pressure and heart rate rest. This is because training improve the health of heart and blood pressure allowing cardiovascular system to function efficiently. When exercise heart's contraction also increases while exercising, there more blood is pumped with each beat. Both groups reported excellent adherence to the task instructions.

In this study the result of tera gymnastic is significant $(p=0,000)$ can improved lower blood pressure patient with hypertension. Tera gymnastics prioritizes gymnastics breathing, where the movements synchronized with meridian patterns with dots health according to the theory of acupuncture. If gymnastics is well done and true as well regularly in the long term, have an impact positives that can help accelerate healing prevents illness as well. That sympathetic nerve activity is reduced when subject breathe slowly. Physical activity carried out by programmed, measurable, regular and routine can reduce the potential for stress, other than that also able to maintain one's physical fitness (Sukadiyanto, 2010). Tera gymnastics contains two elements therapy physical activity and relaxation. Physical activity is obtained through components of stretching and joint motion whereas relaxation is obtained through the respiratory movement that exists in Tera gymnastics (Sari, 2011). the nurses in improving self-care agency of hypertension patients must concern about patient lifestyle and help patient to modify their lifestyle (Kharisna et al., 2018).

Risk factors that can be changed in patients hypertension is the same as recommended for patients other hypertensive patients such as reduction weight, sodium restriction on food, increased physical activity and reduced intake alcohol. This factor not only reduces the pressure blood but also have a positive impact against the risk of cardiovascular disease. This tera gymnastic exercise is good 
Hesti Platini: Tera Gymnastic Effective for Patient with Hypertension

physical activity for patient with high blood hypertension.

The tera gymnastic exercise conditioning program achieved effect in this population. Research from Lewa, Pramantara, Rahayujati (2010) showed that the elderly are not active physical increases the risk of HST events of 2.33 times greater than with the elderly who are physically active, and in a manner statistically significant $(p$-value $=0.003$ ). Investigation of the role of physical exercise regularly to decrease arterial strain center due to age. They found that aerobic exercise and Resistance can regularly inhibit reduction of arterial compliance result increase in age and restore level parallel to the arterial level of age compliance middle-aged. Impact of pressure drop blood because of this sport may be caused by diminished arterial stiffness.

Repetitive exercise with high intensity, the central nervous system will stimulate the muscles and as many muscle fibers as possible resulting in faster contraction, strength and higher endurance. Human body require energy to maintain survival of the body's organs, the process of replacing damaged cells and activity daily. Energy can be defined as capacity or ability to perform work. Work is defined as a style done at a certain distance.

\section{Conclusion}

The reduction of blood pressure after exercise is of great clinical relevance. Which is compatible with observational studies that concluded that exercise and fitness are inversely related to the later development of hypertension. Although there are fewer data on resistance training, the data suggest that resistance training of moderate intensity is able to reduce blood pressure. Various approaches have been used to increase physical activity and maintain adherence. Our results support the recommendation that exercise is a cornerstone therapy for the prevention, treatment and control of hypertension .The increased risk of physical inactivity in controlling hypertension in our study suggest that general practitioners must be in the habit of prescribing practice of physical exercise. Physical activity has been shown to have beneficial effect on blood pressure. patients are followed up regularly to confirm that they are adhering to the management plan and the blood pressure targets.

\section{References}

Arima, H., Barzi, F., \& Chalmers, J. (2011). Mortality patterns in hypertension. Journal of hypertension, 29, S3-S7.

Ciolac, E. G., Bocchi, E. A., Bortolotto, L. A., Carvalho, V. O., Greve, J. M., \& Guimarães, G. V. (2010). Effects of high-intensity aerobic interval training vs. moderate exercise on hemodynamic, metabolic and neuro-humoral abnormalities of young normotensive women at high familial risk for hypertension. Hypertension Research, 33(8), 836.

Eriyanti, M., Widodo, A., \& Jadmiko, A. W. (2016). Pengaruh senam tera terhadap penurunan tekanan darah pada lansia dengan hipertensi di Posyandu Lansia Kelurahan Pabelan Kartasura. (The effect of tera exercise on reducing blood pressure in the elderly with hypertension at the Posyandu Lansia Kelurahan Pabelan Kartasura). Doctoral dissertation, Universitas Muhammadiyah Surakarta.

Ghadieh, A. S., \& Saab, B. (2015). Evidence for exercise training in the management of hypertension in adults. Canadian Family Physician, 61(3), 233-239.

Guimaraes, G. V., Ciolac, E. G., Carvalho, V. O., D'Avila, V. M., Bortolotto, L. A., \& Bocchi, E. A. (2010). Effects of continuous vs. interval exercise training on blood pressure and arterial stiffness in treated hypertension. Hypertension Research, 33(6), 627. http://www.depkes.go.id/article/ view/19051700002/hipertensi-penyakitpaling-banyak-diidap-masyarakat.html.

Gupta, R., \& Guptha, S. (2010). Strategies for initial management of hypertension. Indian Journal of Medical Research. 
Hesti Platini: Tera Gymnastic Effective for Patient with Hypertension

Kemenkes RI. (2019). Hipertensi Penyakit Paling Banyak Diidap Masyarakat, http://www.depkes.go.id/article/ view/19051700002/hipertensi-penyakitpaling banyak-diidap-masyarakat.html.

Lewa, A. F., Pramantara, I. D. P., \& Rahayujati, T. B. (2010). Faktor-Faktor Risiko Hipertensi Sistolik Terisolasi pada Lanjut Usia. Berita kedokteran masyarakat, 26(4), 171.

Kharisna, D., Ropi, H., \& Rahayu, U. (2018). The Factors that are Related to Self-Care Agency in Patients with Hypertension. Jurnal Keperawatan Padjadjaran, 6(1).

Maryam, R. S., Resnayati, Y., Riasmini, N. M., \& Sari, C. W. M. (2018). Effect of Family Support Intervention towards Quality of Life with Elderly's Hypertension in Community. Jurnal Keperawatan Padjadjaran, 6(3).

Parwati, N. M. (2013). Senam tera Indonesia meningkatkan kebugaran jantung paru lansia di Panti Werdha Wana Seraya Denpasar. Public Health and Preventive Medicine Archive, 1(1).
Peri-Okonny, P., Fu, Q., Zhang, R., \& Vongpatanasin, W.(2015).Exercise, the Brain, and Hypertension. Current Hypertension Reports. https://doi.org/10.1007/s11906-0150593-6.

Sari, R. P., \& Kamil, E. N. (2017). Pengaruh Senam Lansia Terhadap Tekanan Darah Pada Lansia Hipertensi Di Puskesmas Walantaka. Jurnal Kesehatan, 6(3), 41-48.

Sukadiyanto, S. (2010). Stress dan Cara Menguranginya. Cakrawala Pendidikan, (1).

World Health Organization. (2013). World health statistics 2013: a wealth of information on global public health (No. WHO/HIS/ HSI/13.1). World Health Organization.

World Health Organization. (2019). Preventing disease through healthy environments: exposure to lead: a major public health concern (No. WHO/CED/PHE/ EPE/19.4. 7). World Health Organization. 